\title{
CAPTURE OF HYPOTHENEMUS HAMPEI FERRARI (COLEOPTERA, SCOLYTIDAE) IN RESPONSE TO TRAP CHARACTERISTICS
}

\author{
Flávia Cloclet da Silva ${ }^{1}$; Maurício Ursi Ventura ${ }^{2 *}$; Lauro Morales ${ }^{3}$ \\ ${ }^{1}$ UEL/CCA - Programa de Pós-Graduação em Agronomia. \\ ${ }^{2}$ UEL/CCA - Depto. Agronomia, C.P. 6001 - 86051-970 - Londrina, PR - Brasil. \\ ${ }^{3}$ EMATER - Escritório Regional de Londrina, km 375 - 86047-902 - Londrina, PR - Brasil. \\ *Corresponding author <mventura@uel.br>
}

\begin{abstract}
Traps lured with semiochemical have been proposed to manage the coffee berry borer, coffee planting is however made under several environmental conditions that may affect the efficacy of traps. Several trap designs and variations were proposed and, therefore, a series of field experiments was carried out to capture coffee berry bores in traps disposed in a low density coffee plantations in the Northern part of the State of Paraná, Brazil. Traps were composed of plastic bottles (2 L) with a window $(13 \times 18 \mathrm{~cm})$. Ethanol $(\mathrm{E})$, Methanol $(\mathrm{M})$ and coffee oil alone did not improve the capture when transparent traps with a $2 \mathrm{~mm}$ hole in the vial dispenser were used; traps lured with $\mathrm{E}: \mathrm{M}$ mixtures $(1: 1,1: 2,1: 3)$ caught similar and higher number of insects than the control. There was synergism with the mixing of $\mathrm{E}$ and $\mathrm{M}$; the addition of coffee oil to the mixtures did not improve the capture. Trap lured with E : M (1:1) mixtures at $342,400,428$ and $710 \mathrm{mg}$ caught similar numbers of insects. Transparent green trap, transparent trap and red trap lured with $642 \mathrm{mg} \mathrm{day}^{-1}$ of the $\mathrm{E}+\mathrm{M}$ (1:1) mixture caught similar numbers of insects. Interaction between colors (transparent green, transparent and red) and semiochemical release rates (540, 720 and $1100 \mathrm{mg} \mathrm{day}{ }^{-1}$ ) was observed. Transparent green trap, when lured with $720 \mathrm{mg} \mathrm{day}^{-1}$ of the $1: 1 \mathrm{E}: \mathrm{M}$ mixture caught 2.3 and 4.4 times more insects than 540 and $1100 \mathrm{mg} \mathrm{day}^{-1}$; and caught 3.2 times more insects than transparent and red trap at the same release rates.

Key words: semiochemical, attractant, volatile, trap color

\section{CAPTURA DA BROCA-DO-CAFÉ, HYPOTHENEMUS HAMPEI (COLEOPTERA,SCOLYTIDAE), EM RESPOSTAA CARACTERÍSTICAS DE ARMADILHAS}

RESUMO: Armadilhas iscadas com semioquímicos têm sido propostas para manejo da broca-docafé. O cafeeiro é cultivado em condições ambientais diversas que podem afetar a eficiência das armadilhas. Vários modelos de armadilha e variações nos modelos são utilizados. Uma série de experimentos de campo objetivou avaliar capturas da broca-do-café em armadilhas numa lavoura de café semi-adensado no Norte do Paraná. Uma garrafa plástica $(2 \mathrm{~L})$ com uma abertura $(13 \times 18 \mathrm{~cm})$ constituiu a armadilha. O etanol (E), metanol (M) e óleo de café, sozinhos, não incrementaram as capturas quando se utilizaram armadilhas transparentes com um frasco difusor com furo de $2 \mathrm{~mm}$; armadilhas iscadas com as misturas $1: 1,1: 2$ e $1: 3$ de etanol (E) + metanol (M) capturaram quantidades similares e superiores à testemunha; sinergismo ocorreu pela mistura de etanol e metanol; a adição do óleo de café às misturas não incrementou as capturas. Armadilhas com taxas de liberação da mistura E:M (1:1) de 342, 400, 428 e $710 \mathrm{mg} \mathrm{dia}^{-1}$ capturaram quantidades similares. Armadilhas verdes transparentes, transparentes e vermelhas, iscadas com E:M (1:1) (642 $\left.\mathrm{mg} \mathrm{dia}^{-1}\right)$ capturaram quantidades similares. Foi observada interação entre as cores (verde transparente, transparente, vermelha) e taxas de liberação dos semioquímicos (540, 720 e $1100 \mathrm{mg} \mathrm{dia}^{-1}$ ). Armadilhas verdes transparentes, quando iscadas com doses de $720 \mathrm{mg} \mathrm{dia}^{-1}$ da mistura 1:1 de E:M, capturaram 2,3 e 4,4 mais insetos do que 540 e $1100 \mathrm{mg} \mathrm{dia}^{-1}$; e capturaram 3,2 mais insetos do que armadilhas transparentes e vermelhas.

Palavras-chave: semioquímico, atraente, volátil, cor de armadilha

Sci. Agric. (Piracicaba, Braz.), v.63, n.6, p.567-571, November/December 2006 


\section{INTRODUCTION}

The coffee berry borer (CBB) Hypothenemus hampei Ferrari is the major pest of coffee plantations worldwide. Chemical control and cultural practices have been the principal strategies to reduce CBB populations in the field (Gutierrez-Martinez \& Ondarza, 1996). Biological control using parasitoids and entomopathogens has been attempted but with limited results (Barrea et al., 2004). The insecticide endosulfan is the main active ingredient used in the CBB management. However, reports of endosulfan resistance in CBB populations (Brun et al., 1989) have shown the importance of developing alternative measures.

Scolytids are attracted to ethanol (E) (Moeck et al., 1981) and methanol (M) (Moeck, 1970) and this is also true for CBB in the field (Mendonza Mora, 1991; Mathieu et al., 1999). It is probable that the conditions under which coffee is grown (climate, spacing, shade, cultivar, plant age, wind direction, speed etc) may affect trapping efficiency. This can induce some discrepancy in results involving capture of $\mathrm{CBB}$ in response to semiochemicals, which may interact with other factors. For example, some studies show a decreasing capture of $\mathrm{CBB}$ with the increase of release rate of 1:3 E:M mixtures (Mendonza Mora, 1991; Mathieu et al., 1997) while others presented the opposite effect (Borbón-Martinez et al., 2000). Red traps captured more CBB than white traps under semi natural conditions (Mathieu et al., 1997) but the opposite occurred in another field study (Borbón-Martinez et al., 2000).

A trap design made with a plastic bottle (soft drink container) baited with an E:M 1:3 mixture and coffee oil was recently proposed for mass trapping CBB (Villacorta et al., 2001). Refinements in trap characteristics might contribute to reduce trap costs and improve competetivity.

A series of field tests were conducted in a coffee plantation (low density) to assess CBB responses to semiochemicals (E, M and coffee oil) alone or mixed; to E:M release rates; to trap colors and the interaction of trap colors and release rates.

\section{MATERIAL AND METHODS}

Field experiments were carried out in Londrina $\left(23^{\circ} 19^{\prime} \mathrm{S}, 51^{\circ} 12^{\prime} \mathrm{W}\right)$, in the state of Paraná, Brazil in a 5 ha organic coffee plantation $(2.0 \times 0.6 \mathrm{~m})$, cv. Catuai. Plants were about $1.6 \mathrm{~m}$ high. Unless otherwise stated, traps were formed with $2.0 \mathrm{~L}$ transparent plastic bottles (originally used as a soft drink container) with a window $(13.0 \times 18.0 \mathrm{~cm})$ of $9.0 \mathrm{~cm}$ above the bottom (adapted from Villacorta et al., 2001). Water and detergent (200 and $2 \mathrm{~mL}$, respectively) were added to the bottom of the bottles trap to kill and retain adult CBB. A $10 \mathrm{~mL}$ amber glass vial with a plastic cover was used as a semiochemical dispenser. Unless otherwise stated, a perforation of $2 \mathrm{~mm}$ in diameter was made on the cover to allow the emanation of semiochemicals. The vial was hung inside the bottle, $20 \mathrm{~cm}$ above the bottom of the trap. Water and semiochemicals were replaced every three days. In the assessments, water with dead insects was removed to the laboratory for counting. Traps were attached to wood stakes $1.20 \mathrm{~m}$ above ground, between plant rows. Distance between traps was $12 \mathrm{~m}$ within a block, and $15 \mathrm{~m}$ between blocks.

\section{Semiochemicals}

In a first experiment, traps baited with $\mathrm{E}, \mathrm{M}$, $\mathrm{E}+\mathrm{M}(1: 1,1: 2$ and 1:3) and water (control) were compared using eight replicates. They were installed on May 17, 2003 and the captures were assessed on May 19, 26, 30 and June 02, 2003.

In a second experiment, the effect of adding $0.5 \%$ coffee oil to the mentioned semiochemical mixtures and of coffee oil alone, was assessed using six replicates. Traps were installed on June 16, 2003 and captures were assessed on June 19, 27, 30; July 4, 14, 17 and 24, 2003.

\section{Semiochemical release rates}

Treatments were $342.0 ; 400.0 ; 428.0$; and $710.0 \mathrm{mg}$ day $^{-1}$ of the E : M (1:1) proportion. Different release rates were obtained using different wire diameters to hold the vial plastic cover $(0.7,1.0,1.6$ and $2.8 \mathrm{~mm}$ ) using five replicates. Traps were installed on September 2 and assessments were conducted on September 05, 14 and 29, 2003.

\section{Trap colors}

Transparent, transparent green and red traps were used, the transparent and transparent green originally used as soft drink containers, can easily be obtained from recycling posts. These last ones have been proposed elsewhere (Villacorta et al., 2001 and Barrera et al., 2004) and farmers use both due to their availability, without information about their relative efficiency. Red traps were also used because previous studies reported an attraction of coffee berry borers to the red color which mimic the color of ripe berries (Mendonza Mora, 1991; Giordanengo et al., 1993) and were prepared by coating transparent bottles with red paint (Coral Dulux $^{\circledR}, 350$ red). Traps were baited with an Ethanol : Methanol mixture (1:1). These traps were installed on October 31, 2003, and assessments were conducted on November 7, 11, 14 and 19, 2003, with seven replicates. 


\section{Trap colors versus release rates}

The capture of transparent, transparent green and red traps at 540, 720 and $1,100 \mathrm{mg} \mathrm{day}^{-1}$ release rates was also assessed, using three traps per treatment. They were installed on March 9, 2003, and assessments were conducted on March 16, 19, 23 and 26, and April 2 and 8, 2003 and the mean obtained for each date was considered as a replicate.

\section{Experimental design and statistical analysis}

The randomized complete block design, was used transforming data $x$ into $\sqrt{x+1}$ for normalization and reduction of the heterogeneity of the variances. A one-way analysis of variance (ANOVA) was performed followed by the Tukey test $(P<0.05)$ to compared means (Tukey, 1949). A two-way ANOVA was performed for the study of the interactions between trap colors and release rates.

\section{RESULTS AND DISCUSSION}

In general, trap baited with the mixtures E:M attracted more CBB beetles than the compounds alone and the control (Table 1). Synergism was found when $\mathrm{E}$ and $\mathrm{M}$ were mixed, since a minimum of 2.7 times more beetles were caught by traps lured with the mixtures of the two compounds (1:1) as compared to the total sum of the captures of the two compounds alone. These results are in agreement with previous studies carried out by Mendonza Mora (1991). Synergism occurred independently of the proportions used (Table 1). Differences between captures in traps baited with the different mixtures were not found. The similarity of the captures with traps with 1:1 and 1:3 E:M mixtures contributes to cost reduction, since $M$ is four times more expensive than E. When used alone, $\mathrm{E}$ and $\mathrm{M}$ did not improve the capture. $\mathrm{E}$ and $\mathrm{M}$ were reported to attract 13 times more CBB beetles than control traps (Mendonza Mora, 1991) and were also mentioned as attractive to other scolytids (Moeck, 1970, Moeck et al., 1981).

Traps baited with coffee oil did not capture more beetles than the control and adding it to the E:M mixture did not improve captures (Table 2). Similar captures among the mixtures $(1: 1,1: 2,1: 3)$ of $\mathrm{E}: \mathrm{M}$ were again found and are in agreement with the results presented in Table 1. A greater attraction of CBB females to plant extracts was previously correlated with increasing caffeine contents and adding extracts of mature coffee fruit and pure caffeine to $\mathrm{E}$ improved the captures of E (Gutierrez-Martinez \& Ondarza, 1996) and E:M mixture lured trap (Gutierrez-Martinez et al., 1993).

Similar captures among traps baited with the (1:1) E:M mixture at different semiochemical release rates are shown in Figure 1. These results diverge from the previous studies in which trap captures decreased with rising rates of (1:3) E:M (from 120 to $240 \mathrm{mg}$ day $^{-1}$ ) in a $3.0 \times 1.5 \mathrm{~m}$ coffee plantation (Mendonza Mora, 1991). This level of responses to E:M 1:1 mixtures was confirmed by traps set up in a tent where CBB females were released $\left(0.5,1.0\right.$ and $20 \mathrm{~g}$ day $\left.^{-1}\right)$ (Mathieu et al., 1997). However, there was an increase in the captures of CBB with rising rates of 1:3 M:E (22 to $186 \mathrm{mg} \mathrm{day}^{-1}$ ) in a coffee plantation in Nicaragua (Borbón-Martinez et al., 2000). Different trap designs were used in each study.

Transparent green, red and transparent traps captured daily means of 30.5, 15.9 and 20.8 beetles per trap, but the differences were not significant (Figure 2). Red trap captured more beetles than transparent trap when attached to the branches of coffee trees and an apparent effect of the background contrast was also related to attraction (Mathieu et al., 1997).

Table 1 - Mean number $( \pm$ SE) of adult coffee berry borers caught daily per trap containing concentrations of ethanol:methanol (E:M). Londrina, (May 17 to June 2, 2003), Brazil.

\begin{tabular}{lccccc}
\hline Treatment & \multicolumn{5}{c}{ Date } \\
\hline & May 19 & May 26 & May 30 & June 02 & Total \\
\hline Water & $0.6 \pm 1.8 \mathrm{~b}$ & $0.6 \pm 3.2 \mathrm{c}$ & $0.4 \pm 0.2 \mathrm{~b}$ & $1.1 \pm 0.8 \mathrm{c}$ & $2.8 \pm 0.4 \mathrm{~b}$ \\
E & $2.8 \pm 1.1 \mathrm{~b}$ & $4.6 \pm 2.2 \mathrm{c}$ & $0.2 \pm 0.1 \mathrm{~b}$ & $3.8 \pm 1.9 \mathrm{c}$ & $11.4 \pm 2.7 \mathrm{~b}$ \\
M & $4.3 \pm 1.8 \mathrm{~b}$ & $17.5 \pm 9.3 \mathrm{bc}$ & $13.0 \pm 4.1 \mathrm{ab}$ & $37.6 \pm 23.2 \mathrm{bc}$ & $72.4 \pm 20.0 \mathrm{~b}$ \\
E:M (1:1) & $48.2 \pm 17.1 \mathrm{a}$ & $70.2 \pm 27.7 \mathrm{ab}$ & $29.1 \pm 13.4 \mathrm{a}$ & $83.6 \pm 21.6 \mathrm{ab}$ & $231.1 \pm 34.3 \mathrm{a}$ \\
E:M (1:2) & $46.0 \pm 15.8 \mathrm{a}$ & $117.6 \pm 36.3 \mathrm{a}$ & $29.6 \pm 12.1 \mathrm{a}$ & $146.5 \pm 41.0 \mathrm{a}$ & $339.7 \pm 80.1 \mathrm{a}$ \\
E:M (1:3) & $61.6 \pm 20.0 \mathrm{a}$ & $121.9 \pm 37.0 \mathrm{a}$ & $29.6 \pm 8.4 \mathrm{a}$ & $120.2 \pm 50.2 \mathrm{a}$ & $333.3 \pm 64.9 \mathrm{a}$ \\
\hline Different letters in the
\end{tabular}

Sci. Agric. (Piracicaba, Braz.), v.63, n.6, p.567-571, November/December 2006 
Table 2 - Mean number ( \pm SE) of adult coffee berry borers caught daily per trap containing different concentrations of E:M and coffee oil $(0.5 \%)$. Londrina, (June 16 to July 24, 2003), Brazil.

\begin{tabular}{|c|c|c|c|c|c|c|c|c|}
\hline \multirow[t]{2}{*}{ Treatment } & \multicolumn{8}{|c|}{ Date } \\
\hline & June 19 & June 27 & June 30 & July 4 & July 14 & July 17 & July 24 & Total \\
\hline Water & $2.8 \pm 1.3 \mathrm{c}$ & $7.3 \pm 6.9 \mathrm{bc}$ & $0.0 \pm 0.00 \mathrm{c}$ & $0.2 \pm 0.2 b$ & $1.8 \pm 1.1 \mathrm{c}$ & $1.3 \pm 0.9 \mathrm{a}$ & $2.3 \pm 1.33 \mathrm{~b}$ & $15.7 \pm 7.2 b$ \\
\hline Coffee oil & $6.7 \pm 2.2 \mathrm{bc}$ & $1.8 \pm 0.9 \mathrm{c}$ & $0.3 \pm 0.2 \mathrm{bc}$ & $0.3 \pm 0.2 b$ & $2.5 \pm 1.2 \mathrm{c}$ & $2.0 \pm 0.9 \mathrm{a}$ & $1.7 \pm 0.8 \mathrm{~b}$ & $15.3 \pm 6.2 b$ \\
\hline $\mathrm{E}+\mathrm{M}(1: 1)$ & $82.0 \pm 29.0 \mathrm{a}$ & $105.8 \pm 63.9 \mathrm{ab}$ & $36.3 \pm 37.00 \mathrm{a}$ & $12.7 \pm 2.9 \mathrm{ab}$ & $23.0 \pm 11.4 \mathrm{a}$ & $86.8 \pm 59.5$ a 1 & $149.3 \pm 63.5 \mathrm{a}$ & $495.9 \pm 144.0 \mathrm{a}$ \\
\hline $\mathrm{E}+\mathrm{M}(1: 2)$ & $73.5 \pm 33.2 \mathrm{a}$ & $88.3 \pm 49.6 \mathrm{abc}$ & $36.8 \pm 54.47 \mathrm{a}$ & $13.2 \pm 2.9 \mathrm{ab}$ & $18.7 \pm 12.6 \mathrm{a}$ & $123.5 \pm 69.4 \mathrm{a} 1$ & $27.5 \pm 64.6 \mathrm{a}$ & $481.5 \pm 138.2 \mathrm{a}$ \\
\hline $\mathrm{E}+\mathrm{M}(1: 3)$ & $42.5 \pm 7.8 \mathrm{ab}$ & $59.3 \pm 20.9 a b c$ & $23.3 \pm 25.75 \mathrm{ab}$ & $12.3 \pm 1.2 \mathrm{ab}$ & $18.3 \pm 4.5 \mathrm{a}$ & $101.0 \pm 74.9 a$ & $69.7 \pm 16.6 \mathrm{ab}$ & $326.4 \pm 93.8 \mathrm{a}$ \\
\hline $\begin{array}{l}\mathrm{E}+\mathrm{M}(1: 1)+ \\
\text { coffee oil }\end{array}$ & $52.8 \pm 16.6 \mathrm{ab}$ & $72.8 \pm 28.2 \mathrm{abc}$ & $18.8 \pm 8.33 \mathrm{abc}$ & $10.0 \pm 1.8 \mathrm{ab}$ & $24.5 \pm 6.5 \mathrm{a}$ & $35.17 \pm 8.9 \mathrm{a}$ & $39.3 \pm 15.1 \mathrm{ab}$ & $253.4 \pm 62.3 \mathrm{a}$ \\
\hline $\begin{array}{l}\text { E+M }(1: 2)+ \\
\text { coffee oil }\end{array}$ & $33.5 \pm 9.9 a b c$ & $40.3 \pm 13.5 \mathrm{abc}$ & $25.3 \pm 17.82 a$ & $8.8 \pm 0.8 \mathrm{ab}$ & $14.7 \pm 4.7 \mathrm{ab}$ & $28.5 \pm 15.6 \mathrm{a}$ & $59.8 \pm 24.5 \mathrm{ab}$ & $210.9 \pm 49.3 \mathrm{ab}$ \\
\hline $\begin{array}{l}\text { E+M }(1: 3)+ \\
\text { coffee oil }\end{array}$ & $58.7 \pm 33.9 \mathrm{ab}$ & $124.2 \pm 51.9 \mathrm{a}$ & $59.3 \pm 68.88 \mathrm{a}$ & $22.0 \pm 4.0 \mathrm{ab}$ & $13.0 \pm 4.8 \mathrm{abc}$ & $57.2 \pm 26.8 \mathrm{a}$ & $49.7 \pm 18.5 \mathrm{ab}$ & $384.02 \pm 104.5 \mathrm{a}$ \\
\hline
\end{tabular}

Different letters in the same column indicate difference according to Tukey test with $P>0.05 ; \mathrm{n}=6$.

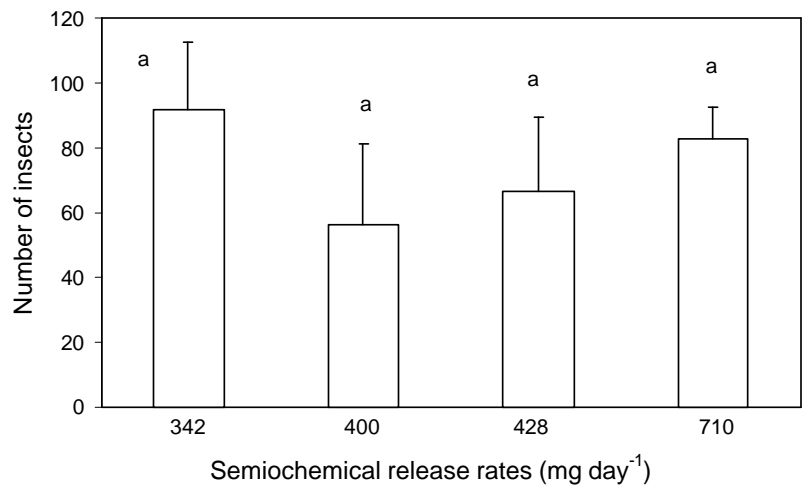

Figure 1 - Mean number $( \pm$ SE) of adult of coffee berry borers caught daily per traps with different release rates of the ethanol : methanol (1:1) mixture. Londrina, PR. September 2 to 29, 2003. Mean of three assessments conducted on September 05, 14 and 29, 2003. Bars with different letters are different, based on the Tukey test $(P<0.05), \mathrm{n}=5$.

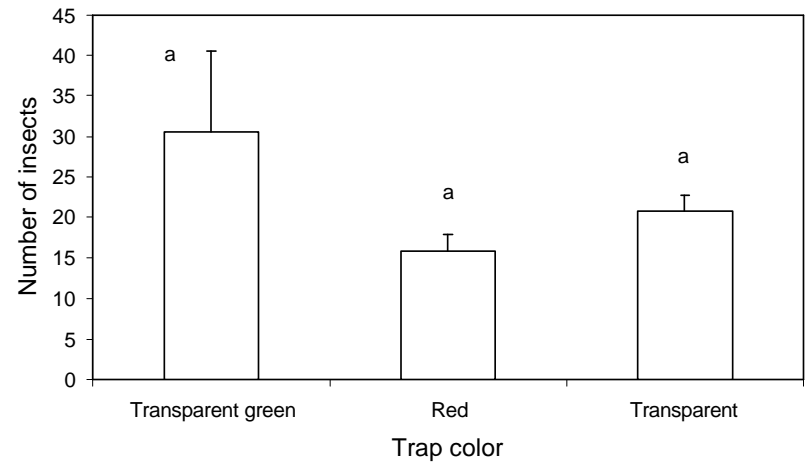

Figure 2 - Mean number $( \pm$ SE) of adult coffee berry borers caught daily per traps of different colors. Londrina, PR. (October 31 to November 19, 2003). Mean of four assessments conducted on November 7, 11, 14 and 19, 2003. Bars with different letters are different, based on the Tukey test $(P<0.05), \mathrm{n}=7$.
Table 3 - Mean number ( \pm SE) of adult coffee berry borers caught daily per transparent, transparent green and red traps containing different release rates of 3:1 E:M mixtures. Londrina, March 9 to April, 2003. Means of six assessments conducted on March 16, 19, 23 and 26 and April 2 and 8, 2003, Brazil.

\begin{tabular}{llrl}
\hline \multirow{2}{*}{ Rate } & \multicolumn{3}{c}{ Trap Color } \\
\cline { 2 - 4 } & Transparent & $\begin{array}{c}\text { Transparent } \\
\text { green }\end{array}$ & Red \\
\hline mg day $^{-1}$ & & & \\
540 & $1.85 \mathrm{Aa}$ & $4.68 \mathrm{Ba}$ & $3.92 \mathrm{Aa}$ \\
720 & $3.31 \mathrm{Ab}$ & $10.71 \mathrm{Aa}$ & $3.31 \mathrm{Ab}$ \\
1,100 & $2.45 \mathrm{Aa}$ & $2.47 \mathrm{Ba}$ & $2.73 \mathrm{Aa}$ \\
\hline
\end{tabular}

Different letters in the same column indicate statistical difference according to Tukey test with $P>0.05, \mathrm{n}=6$.

An interaction between trap colors and semiochemicals release rates was found $(\mathrm{F}=7.2440$ **). Transparent green trap, when lured with rates of $720 \mathrm{mg}$ day $^{-1}$ of 1:1 E:M mixtures, captured 2.3 and 4.3 times more beetles than 540 and $1,100 \mathrm{mg} \mathrm{day}^{-1}$ respectively, and 3.2 times more beetles than transparent and red traps lured with the same semiochemical at the same release rates. Interactions between trap colors and release rates were reported when transparent and red traps were used at $0.5,1.5$ and $20 \mathrm{mg}$ $\operatorname{day}^{-1}$ of the 1:1 E:M mixture (Mathieu et al., 1997). For other insect species, interaction between trap and attractant has been reported. For D. virgifera virgifera, interactions were reported between trap collor and kind of attractant (Hesler \& Suter, 1993).

Damon (2000) reviewed the CBB attraction to coffee berries and concluded that the information available was still confusing and conflicting, and could not 
be used to design monitoring and control techniques such as color or kairomone traps. Although progress have been added after this manifestation, authors have emphasized the importance of continuous investigation on the subject (Mendonza Mora, 1991; Mathieu et al., 1999). Conflicting results of laboratory studies may mostly reflect the physiological conditions of the beetles and the differences in bioassay procedures. When females leave the berries they are called colonizing females and respond to fruit berry volatile stimulus. However, some females lay their eggs in the original berry and do not respond to the same attractants (Mathieu et al., 2001). In the field, responses are exclusively obtained with colonizing females and discrepancies in the results are probably related with environmental and farming system conditions under which the studies were conducted; the trap characteristics and interactions among several factors affecting CBB captures. Under no-shade conditions, the efficacy of traps may be severely reduced (Dufour, 2004).

In short, when using transparent bottle traps, E, $\mathrm{M}$ and coffee oil alone did not improve the attraction of CBBs; trap lured with 1:1 E:M mixtures captured a similar mean number of CBBs for $1: 2$ and 1:3 mixtures; coffee oil added to the E:M mixture did not improve captures; similar captures of CBB females using 342, 400, 428 and $710 \mathrm{mg} \mathrm{day}^{-1}$ release rates of 1:1 E:M mixtures were found. Transparent green, transparent and red traps caught similar numbers of CBB female beetles; interaction between trap colors and release rates was found; transparent green trap, when lured with rates of $720 \mathrm{mg}$ day $^{-1}$ of 1:1 E:M mixtures, captured 2.3 and 4.3 times more beetles than 540 and $1,100 \mathrm{mg} \mathrm{day}{ }^{-1}$, respectively; and 3.2 times more beetles than transparent and red traps at the same release rates. These data suggest the utilization of the transparent green trap, lured with 1:1 E:M mixture at $720 \mathrm{mg} \mathrm{day}^{-1}$ under similar planting conditions in which the experiments were carried out. Further field investigations should be carried out to establish trap density need to reduce the pest below the control threshold.

\section{REFERENCES}

BARRERA, J.F.; VILLACORTA, A.; HERRERA, J. Fluctuación estacional de las capturas de la Broca del café (Hypothenemus hampei) con trampas de etanol- metanol e implicaciones sobre el número de trampas. Entomología Mexicana, v.3, p.540544, 2004.

BORBÓN-MARTINEZ, O.; ALFARO, O.M.; OEHLSCHLARGER, A.C.; GONZALEZ, L.M. Proyecto de trampas, atrayentes y repelentes para el control de la broca del fruto de cafeto, Hypothenemus hampei L. (Coleoptera: Scolytidae). In: SIMPOSIO LATINOAMERICANO DE CAFEICULTURA, 19., San José, 2000. Proceedings. San José: IICA, 2000. p.331348 .
BRUN, L.O.; OEHLSCHLAGER, A.C.; GAUDICHON, V.; SUCKLING, D.M. Endosulfan resistance in the coffee berry borer Hypothenemus hampei (Coleoptera: Scolytidae) in New Caledonia. Journal of Economic Entomology, v.82, p.13111316.

DAMON, A. A review of the biology and control of the coffee berry borer, Hypothenemus hampei (Coleoptera: Scolytidae). Bulletin of Entomological Research, v.90, p.453-465, 2000.

DUFOUR, B.P. Condiciones de uso de las trampas en el control de la broca del café. In: WORKSHOP INTERNACIONAL SOBRE MANEJO DA BROCA-DO-CAFÉ, Londrina, 2004. Proceedings. Londrina: IAPAR, 2004. p.7.

GIORDANENGO, P.; BRUN, L.O.; FREAROT, B. Evidence for allelochemical attraction of the coffee berry bore, Hypothenemus hampei, by coffee berries. Journal of Chemical Ecology, v.19, p.763-769, 1993.

GUTIÉRREZ-MARTÍNEZ, A.; ONDARZA, R.N. Kairomone effect of extracts from Coffea canephora over Hypothenemus hampei (Coleoptera: Scolytidae). Environmental Entomology, v.25, p.96-100, 1996.

GUTIÉRREZ-MARTÍNEZ, A.; RIVAS, S.H.; SANCHEZ, A.V. Atracción química de la broca del fruto de café Hypothenemus hampei Ferrai (Coleoptera: Scolytidae) por las diferentes variedades de café en el Sononusco, Chiapas, México. In: SIMPOSIO LATINOAMERICANO DE CAFEICULTURA, 16., Managua, 1993. Proceedings. Manágua: IICA, 1993. p.1-8.

HESLER, L.S.; SUTTER, G.R. Effect of trap color, volatile attractants and type of toxic bait dispenser on captures of adults rootworm beetles (Coleoptera: Chrysomelidae). Environmental Entomology, v.22, p.743-750, 1993.

MATHIEU, F.; BRUN, L.O.; MARCILLAUD, C.; FREROT, B. Trapping of the coffee berry borer within a mesh-enclosed environment: interaction of olfactory and visual stimuli. Journal of Applied Entomology, v.121, p.181-186, 1997.

MATHIEU, F.; BRUN, L.O.; FREROT, B.; SUCKLING, D.M.; FRAMPTON, C. Progression in field infestation is linked with trapping of coffee berry borer, Hypothenemus hampei (Col., Scotytidae). Journal of Applied Entomology, v.123, p.535540, 1999.

MATHIEU, F.; GAUDICHON, V.; BRUN, L.O.; FREROT, V. Effect of physiological status of olfactory and visual responses of females Hypothenemus hampei during host plant colonization. Physiological Entomology, v.26, p.189-193, 2001.

MENDONZA MORA, J.R. Resposta da broca-do-café, Hypothenemus hampei, a estímulos visuais e semioquímicos. Viçosa: UFV, 1991. 44p. (Thesis - M.S.).

MOECK, H.A. Ethanol as the primary attractant for the ambrosia beetle Typodendron lineatum (Coleoptera: Scolytidae). Canadian Entomologist, v.102, p.985-994, 1970.

MOECK, H. A.; WOOD, D.L.; LINDAHL, K.Q. host selection behavior of bark beetles (Coleoptera, Scolytidae) attracting Pinups ponderosa, with special emphasis on the western pinebeetle, Dendroctonus brevicomis. Journal of Chemical Ecology, v.7, p.49-83, 1981.

TUKEY, J.W. One degree of freedom for non-additivity. Biometrics, v.5, p.232-242, 1949.

VILlaCORTA, A.; POSSAGNOLO, A.F.; SILVA, R.Z.; RODRIGUES, P.S. Um modelo de armadilha com semioquímicos para o manejo integrado da broca do café Hypothenemus hampei (Ferrari) no Paraná.. In: SIMPÓSIO BRASILEIRO DE PESQUISA DOS CAFÉS DO BRASIL, 2, Vitória, 2001. Proceedings Brasília: Embrapa Café, 2001. p.2093-2098.

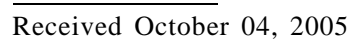

Accepted September 13, 2006 